\title{
Records of performance and sanitary status from a dairy cattle herd in southern Brazil ${ }^{1}$
}

\author{
Cláudio E.F. Cruz², Djeison L. Raymundo², Cristine Cerva ${ }^{3}$, Saulo P. \\ Pavarini $^{2}$, André G.C. Dalto ${ }^{2}$, Luís G. Corbellini ${ }^{4}$ and David Driemeier ${ }^{2 *}$
}

\begin{abstract}
Cruz C.E.F., Raymundo D.L., Cerva C., Pavarini S.P., Dalto A.G.C., Corbellini L.G. \& Driemeier D. 2011. Records of performance and sanitary status from a dairy cattle herd in southern Brazil. Pesquisa Veterinária Brasileira 31(1):1-9. Setor de Patologia Veterinária, Faculdade de Veterinária, Universidade Federal do Rio Grande do Sul, Av. Bento Gonçalves 9090, Porto Alegre, RS 91540-000, Brazil. E-mail: davetpat@ ufrgs.br

Over the last decades, the emphasis on the health of dairy cows has changed from an individual to a herd level. In this scenario, the role played by the recording system and its interpretation by veterinarians has gained primordial importance. The records of productive and reproductive performance and of sanitary status from a southern Brazilian dairy cattle herd have been presented and discussed. The period of study was 2000-2009. Mean values per lactation period were 349D 8436M 290F 275P 201SCS (D: days in lactation, $\mathrm{M}$ : $\mathrm{kg}$ of milk yield, $\mathrm{F}: \mathrm{kg}$ of fat, $\mathrm{P}: \mathrm{kg}$ of protein and SCS: somatic cell score in $1000 \mathrm{cells} / \mathrm{ml}$ of milk). Major indexes of reproductive efficiency included age at first calving (31 months), services per conception (2.1), intercalving interval (428 days), calving to conception interval (146 days), mean annual rates of parturitions $(76.2 \%)$, fetal losses (9.8-19.0\%), and stillbirths (3.6\%), apart of voluntary waiting period (94 days). Main information on sanitary status of the herd was associated with the mean prevalence of common disorders of dairy cattle such as anaplasmosis $(29.8 \%)$, mastitis $(27.8 \%)$, digital diseases $(26.3 \%)$, ovarian cysts $(21.3 \%)$, placental retention $(19.7 \%)$, postpartum uterine infections (10.6\%), and calf diarrhea (23.7\%) and pneumonia (16.8\%), among others. In addition, culling reasons (low reproductive performance [56.3\%] and udder/mastitis problems [33.6\%]), causes of cattle deaths (anaplasmosis [16.4\%] and leukosis [11.4]), and the impact of cattle diseases such as tuberculosis, leukosis, and neosporosis on the herd have also been presented and succinctly discussed. Numbers between brackets represent rates accumulated in the 10-year period.
\end{abstract}

INDEX TERMS: Dairy cattle, herd health and management, reproductive efficiency, diseases of cattle, mastitis, cattle losses, culling rates, fetal losses, abortions.

RESUMO.- [Registros de desempenho e de status sanitário de um rebanho bovino leiteiro no Sul do Brasil.] Nas últimas décadas, os cuidados sanitários de vacas lei-

\footnotetext{
${ }^{1}$ Received on June 23, 2010.

Accepted for publication on August 13, 2010.

2 Departamento de Patologia Clínica Veterinária, Faculdade de Veterinária, Universidade Federal do Rio Grande do Sul (UFRGS), Avenida Bento Gonçalves 9090, Porto Alegre, RS 91540-000, Brazil. "Corresponding author: davetpat@ufrgs.br

${ }^{3}$ Laboratório de Virologia, Instituto de Pesquisas Veterinárias Desidério Finamor (IPVDF), Estrada do Conde, $n^{\circ} \mathbf{6 0 0 0}$, Eldorado do Sul, RS 92990-000. E-mail: cristinecerva@ipvdf.rs.gov.br

4 Departamento de Medicina Veterinária Preventiva, Faculdade de Veterinária, UFRGS, Porto Alegre, RS.
}

teiras passaram por um processo de adaptação, no qual o enfoque individual foi substituído pelo coletivo, cujo sistema de manutenção e interpretação de registros por veterinários assumiu papel fundamental. Os registros de eficiência produtiva e reprodutiva, bem como os de ordem sanitária observados em um rebanho bovino leiteiro no Sul do Brasil foram apresentados e discutidos. O período estudado foi 2000-2009. Os dados de produção leiteira média incluíram, por período de lactação de 349 dias, $8436 \mathrm{~kg}$ de leite, $290 \mathrm{~kg}$ de gordura e $275 \mathrm{~kg}$ de proteína, com média de contagem de células somáticas de 201000 células $/ \mathrm{ml}$ de leite. Idade ao primeiro parto (31 meses), serviços por concepção $(2,1)$, intervalo entre partos (428 dias), intervalo par- 
to-concepção (146 dias), taxas médias anuais de parição $(76,2 \%)$, perdas fetais $(9,8-19 \%)$ e natimortos $(3,6 \%)$, além de período de espera voluntária (94 dias) foram alguns dos índices de desempenho reprodutivo registrados. Informações sanitárias do rebanho incluíram prevalência média de doenças comuns em bovinos leiteiros tais como anaplasmose $(29,8 \%)$, mastites $(27,8 \%)$, doenças digitais $(26,3 \%)$, cistos ovarianos $(21,3 \%)$, retenção de placenta $(19,7 \%)$, infecções uterinas $(10,6 \%)$, diarreia $(23,7 \%)$ e pneumonia $(16,8 \%)$ em terneiras, entre outras. Além disso, razões de descartes (baixo desempenho reprodutivo [56,3\%], alterações de úbere [33,6\%], etc.), causas de morte (anaplasmose [16,4\%], leucose [11.4], etc.) e o impacto de doenças de bovinos como tuberculose, leucose e neosporose sobre o rebanho foram também apresentados e sucintamente discutidos. Números entre colchetes representam taxas acumuladas no período 2000-2009.

TERMOS DE INDEXAÇÃO: Bovinos leiteiros, saúde e manejo de rebanho, desempenho reprodutivo, doenças de bovinos, mastites, causas de morte em bovinos, descartes, abate sanitário, perdas fetais, abortos.

\section{INTRODUCTION}

The veterinary medicine of food-producing animals focuses on herd health programs, in which the maintenance of records is a fundamental component that can be used to monitor animal health events, production levels, and the prevalence of diseases (Schwabe 1982, Radostits et al. 1994a). The objectives of herd health programs are met by applying performance targets, which are the levels of animal health and production that are considered to be optimum and yield the best economic returns on investments. These targets are determined based on the performance observed in representative population samples (Radostits et al. 1994a). The surveillance of reproductive performance is one of the major concerns involved in breeding herds. Although reproductive performance targets for Brazilian dairy cattle herds have been addressed (Leite et al. 2001, Grossi \& Freitas 2002, Guimarães et al. 2002, Portela et al. 2002, Val et al. 2004), more comprehensive studies are necessary to define with higher reliability their acceptable ranges. This need becomes more obvious when considered in the context of the country's large size and agricultural diversity as currently observed in Brazil. Therefore, local veterinarians are often compelled to inappropriately apply the numbers recorded for foreign herds. Common causes of low reproductive performance in dairy cattle include deficient nutrition, improper management, seasonal climatic effects, and infectious diseases, among others (Radostits et al. 1994b, Buckley et al. 2000, Demetrio et al. 2007, Pegorer et al. 2007). Similarly, the rates in which cattle diseases occur demonstrate the regular sanitary status of a herd and consequently may indicate risk situations to be deal with. In this scenario of scarcity of information on local herds, the present communication includes the records of performance and sanitary status observed in a dairy cattle herd over a 10-year period in Rio Grande do Sul, Brazil.

\section{MATERIALS AND METHODS}

A herd that expanded from approximately 50 to 250 milking cows in the period 2000-2009 was studied. In 1999, the Holstein herd was introduced in a 1000-hectare farm located in Southern Brazil. Nutritional management was conducted mainly with intensive rotational grazing on mixed ryegrass (Lolium multiflorum), oat (Avena sp.), and white clover (Trifolium repens) pastures in the winter-spring period and millet (Pennisetum glaucum) in the summer months. Diet supplementation included corn (Zea mays) silage; oat or ryegrass haylage, wet brewers grains (brewing beer by-product), commercial concentrates, and mineral mix $^{3}$. Similarly, the young stock was managed at pastures from weaning to pre-calving stage, and received feed supplementation according to their specific nutritional requirements. The milking center comprised a double 8-stall herringbone parlour equipped with automatic extractors and the Delaval ${ }^{4}$ Alpro System (DAS). Milk production was checked monthly and calculated until 2003; afterwards, the daily productions were automatically recorded on the DAS. Animals were mechanically milked twice daily. Milk machine maintenance was provided by Delaval, Brazil. Although breeding programs were based mainly on artificial insemination, selected bulls were raised in the farm and used for natural service. The main objective of the zootechnical improvement program of the herd has been general conformation (type); however, semen from most of the top North American bulls from the world's largest cooperatives of artificial insemination were consistently used in the herd and therefore included also high proofs for milk production. The major goal of the business has been establishing a top zootechnical dairy cattle herd for exhibitions and sales purposes. Milk production was an additional goal. Increments in herd size were also associated with the introduction of heifers from Uruguay (2001) or from local dairy herd liquidations (2006). Reproductive (i.e., artificial insemination, bull service, parturition, abortion, etc.), sanitary (i.e., disease prevalence, metritis, ovarian cysts, somatic cell counts, etc.), and production records (milk production) were saved as Microsoft Excel worksheets, which were updated on a regular basis by the veterinarian in charge. Gestation length was assumed to be 282 days (Morrow 1986). General counts, means, and intervals were calculated using the tools of the Microsoft Excel program.

During the study period, the herd was systematically immunized against brucellosis (B. abortus strain 19 vaccine, all 3- to 8-month-old female calves), leptospirosis (polyvalent vaccines, total herd, 2-3 times annually), foot-and-mouth disease (according to official calendar), and a clostridial polyvalent vaccine (total herd - twice annually). The total herd was tested annually for brucellosis and tuberculosis (TBC). All reactors in tuberculin tests were included in sanitary slaughter program at the farm (euthanasia, necropsy [careful search for typical TBC lesions], and burial using a backhoe loader). Clinical diagnosis and therapy of diseases of cattle were primarily established by the veterinarian, who trained selected workers from the farm staff to recognize and develop specific protocols for most of the common disorders affecting the herd. Tick (Rhipicephalus [Boophilus] microplus) control was achieved through insecticides (amitraz, cypermethrin/dichlorvos) administration by manual pulverization until 2004 and by immersion baths thereafter. Anthelmintic control included regular dosing with intercalating active principles from weaning to precalving stage; immediately after calving, cows were orally dosed 
with levamisole, and at the beginning of the dry period they received a shot of nitroxinil. On the calving day, cows were also injected with calcium solutions. Parturitions were observed overnight by a trained worker and calves received colostrum (from the respective dam or colostrum bank) immediately after birth. Cases of placental retention (fetal membranes [afterbirth] held longer than 12-hour period after calving) or subsequent complications such as metritis and pyometra were treated

Table 1. Indexes of reproductive performance observed in a dairy cattle herd in Rio Grande do Sul, 2000-2009

\begin{tabular}{|c|c|c|c|c|c|c|c|c|c|c|c|}
\hline & 2000 & 2001 & 2002 & 2003 & 2004 & 2005 & 2006 & 2007 & 2008 & 2009 & Average \\
\hline A1C (months) & 35 & 32 & 32 & 32 & 36 & 28 & 30 & 29 & 28 & 29 & 31 \\
\hline Parturitions* (\%) & 76.5 & 73.5 & 71.7 & 70.9 & 74.2 & 76.5 & 79.0 & 78.0 & 80.7 & 81.3 & 76.2 \\
\hline 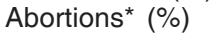 & 5.8 & 4.2 & 5.1 & 2.7 & 4.3 & 6.1 & 5.9 & 4.9 & 6.5 & 7.1 & 5.2 \\
\hline $\mathrm{RHAP}^{*}(\%)$ & 9.8 & 7.1 & 8.6 & 6.8 & 9.1 & 10.0 & 9.8 & 10.6 & 11.9 & 9.8 & 9.4 \\
\hline Stillbirths* (\%) & 4.7 & 2.1 & 3.0 & 3.8 & 3.4 & 3.4 & 3.6 & 4.8 & 4.9 & 2.1 & 3.6 \\
\hline SPC (days) & 1.5 & 1.5 & 1.6 & 2.0 & 2.2 & 2.2 & 1.9 & 2.3 & 2.8 & 2.3 & 2.1 \\
\hline ICI (days) & 390 & 438 & 431 & 420 & 443 & 403 & 412 & 447 & 464 & 436 & 428 \\
\hline CCI (days) & 108 & 156 & 149 & 138 & 161 & 121 & 130 & 165 & 182 & 154 & 146 \\
\hline VWT (days) & 72 & 99 & 107 & 95 & 110 & 76 & 95 & 98 & 89 & 96 & 94 \\
\hline
\end{tabular}

$\mathrm{A} 1 \mathrm{C}=$ age at first calving. $\mathrm{RHAP}=$ cows returning to heat after being diagnosed as pregnant; SPC = number of services per conception; $\mathrm{ICl}=$ intercalving interval; $\mathrm{CCl}=$ calving-conception interval; VPWP = voluntary postpartum waiting period was the mean interval observed between calving and $1^{\text {st }}$ service (extracted from cows that conceived at $1^{\text {st }}$ service). ${ }^{\star}$ Denominators were adjusted to the categories of cattle associated with each event; for example: proportion of parturitions in the total number of animals older than 40 months of age; proportion of abortions and RHAP in the total number of pregnant animals.

Table 2. Comparison on reproductive efficiency of $68 \mathrm{NC}-$ seropositive and $211 \mathrm{NC}-$ seronegative cows from a dairy cattle herd in Rio Grande do Sul

\begin{tabular}{lcc}
\hline & $\begin{array}{c}\text { NC-seropositive } \\
\text { cows }\end{array}$ & $\begin{array}{c}\text { NC-seronegative } \\
\text { cows }\end{array}$ \\
\hline Age at first calving (months) & 42.6 & 31 \\
Parturitions (\%) & 64.2 & 79.4 \\
Stillbirths (\%)* & 33.8 & 9.9 \\
Abortions (\%)* & 61 & 25.6 \\
RHAP (\%)* & 82 & 29.8 \\
Mean SPC & 3.9 & 2.3 \\
Mean ICl & 472 & 428 \\
Mean CCI & 189 & 146 \\
Cull rate (\%)* & 14.7 & 6.6
\end{tabular}

$\mathrm{NC}=$ Neospora caninum; denominators were adjusted to the categories of cattle associated with each event. *Rates accumulated in 2000-2009. systemically with antibiotics, or occasionally with additional local antibiotic solutions and hormonal therapy (prostaglandins, estrogens, or oxytocin). Ovarian cysts were diagnosed by rectal palpation (single follicular structure with a diameter equal or greater than $2.5 \mathrm{~cm}$ in the absence of a corpus luteum, in three successive examinations performed at seven-day intervals) and observation of hyperestrus/anestrus behavior.

Somatic cell counts (SCC), California mastitis test (CMT), bacteriology of milk samples, and determination of milk line were conducted on a quarterly basis. CMT and bacteriology were performed only in high SCC (300.000-1.000.000 cells/ $\mathrm{ml}$ ) cows. Mastitis control included pre-milking udder preparation (pre-dipping and teat drying with paper towel), postdipping, and dry-cow management, among other procedures. Dry-off period was usually 60 days before next calving or longer, if milk production was low and/or calving to conception interval

Table 3. 3463 cases of health disorders affecting a dairy cattle herd from Rio Grande do Sul in the period 2000-2009

\begin{tabular}{lcccccccccccccc}
\hline & \multicolumn{1}{c}{ Year (\%) } & Total \\
\cline { 2 - 12 } & 2000 & 2001 & 2002 & 2003 & 2004 & 2005 & 2006 & 2007 & 2008 & 2009 cases \\
\hline Anaplasmosis & 43.7 & 32.9 & 36.8 & 33.5 & 33.5 & 44.4 & 38.7 & 9.9 & 11.1 & 13.5 & 683 \\
Clinical mastitis & 33.2 & 26 & 26.6 & 27.8 & 26 & 29.2 & 19.2 & 28.8 & 27 & 34.5 & 538 \\
Ovarian cysts & 12.2 & 7.4 & 17.3 & 19.7 & 25.4 & 26.1 & 24.7 & 28.7 & 23.9 & 27.9 & 421 \\
Placental retention & 27.6 & 19.2 & 20.1 & 15.1 & 19.3 & 19.4 & 22.2 & 20.8 & 11.7 & 21.3 & 343 \\
Calf diarrhea & 29.2 & 16.4 & 29.2 & 12.5 & 21.1 & 29.3 & 22.4 & 26.7 & 22 & 27.8 & 225 \\
Digital dermatitis & 19.4 & 8.6 & 7.9 & 5.1 & 10.5 & 7.3 & 11.5 & 9.3 & 17.8 & 16.1 & 205 \\
Claw deformities & 6.1 & 0.9 & 1.4 & 5.6 & 14.4 & 8.7 & 14.1 & 13.4 & 18.4 & 12.2 & 203 \\
Postpartum uterine infection & 18.4 & 11.5 & 12.9 & 10.6 & 12.2 & 8.2 & 8.1 & 5.7 & 7.4 & 11.3 & 174 \\
Calf pneumonia & 28.6 & 10.9 & 19.4 & 10.7 & 17.8 & 14.1 & 17.8 & 19.8 & 14.4 & 14.5 & 147 \\
Adult pneumonia & 8.9 & 8.7 & 5.8 & 5.6 & 8.3 & 7.2 & 4.3 & 7.3 & 3.9 & 4.5 & 112 \\
Solar laminitis sequelae & 5.2 & 2.9 & 2.9 & 4 & 3.9 & 6.3 & 6.8 & 6.9 & 7 & 8.6 & 108 \\
Metabolic diseases & 6.1 & 4.8 & 10.8 & 5.1 & 5 & 5.3 & 5.6 & 6.1 & 4.8 & 5.4 & 104 \\
Babesiosis & 3.2 & 11.9 & 12.1 & 5.9 & 1.8 & 3.5 & 3.5 & 0.8 & 2.2 & 0.9 & 93 \\
Digital trauma & 2.1 & 0 & 0.7 & 1.5 & 2.2 & 0.9 & 1.7 & 2.1 & 5.2 & 7.2 & 49 \\
Abomasal displacement & 0 & 0 & 0.7 & 0 & 0.6 & 0 & 1.2 & 2.8 & 1.3 & 3.6 & 23 \\
Interdigital necrobacilosis & 0 & 1.9 & 0.7 & 0 & 1.1 & 0 & 0.8 & 2.8 & 0.4 & 1.8 & 19 \\
Traumatic reticulitis & 6.1 & 4.8 & 2.8 & 0 & 0.6 & 1 & 0 & 0 & 0.4 & 0 & 16 \\
& & & & & & & & & & & 3463
\end{tabular}

Denominators were adjusted to populations at risk; for example: proportion of calved cows that showed clinical mastitis, ovarian cysts, placental retention, and postpartum uterine infection. 
was extended. Dry cows were treated at least once with longacting antibiotics. Whenever the length of the dry period allowed, additional treatments were performed, especially in Staphylococcus aureus infected cows. Dry cow management also included regular check for udder condition, flame-clipping udders (especially in winter), and teat dipping. Most of the cattle deaths and some occasionally aborted fetuses found were necropsied by the staff from the Setor de Patologia Veterinária (SPV-UFRGS). Complementary histopathology, bacteriology, virology, and toxicology were performed as necessary. Dead animals were buried using a backhoe loader.

\section{RESULTS}

From 2000 to 2009, an annual mean of 195 lactating cows produced on average $8436 \mathrm{~kg}$ of milk, $290 \mathrm{~kg}$ of fat, and 275 $\mathrm{kg}$ of protein. The mean lactation period was 349 days. Average of somatic cell counts ranged from 174000 to 226000 cells $/ \mathrm{ml}$ of milk in the period. The mean number of parturitions per cow was 2.96 , and $60 \%$ of the cows calved up to 4 times. In total, 2045 parturitions (including 74 twin pregnancies) produced 1995 new born calves. There were 79 stillbirths and 45 dead calves between 1 and 6 months old, which represents a total calf loss of $5.9 \%$. In the period studied, heat detection rates varied from 38 to $73 \%$, with the lowest rates occurring in summer months. The indexes of reproductive performance observed in the herd are presented in Table 1. A total of 26 out of 136 aborted fetuses were submitted for diagnosing procedures, of which five had changes consistent with neosporosis, three were associated with hyperthermia due to anaplasmosis, and one was linked to septicemia. A causal agent was not identified in remaining fetuses. Comparative data on performance of Neospora caninum (NC)-seropositive and NC-seronegative cows are shown in Table 2. In 46 (59.7\%) of the 77 NC-seropositive cows, it was possible to identify a dam-daughter relationship. Records on disease prevalence and cattle losses are presented in Table 3 and 4, respectively. Causal agents isolated from 767 high SCC milk samples included coagulase-negative Staphylococcus species (184), Staphylococcus aureus (124), environmental Streptococcus species (63), Corynebacterium bovis (33), Streptococcus agalactiae (24), and Nocardia asteroides (21), among others (17). There was no bacterial growth in 301 milk samples. Most milk samples were collected in summer months (January to March), when mastitis episodes were most prevalent.

\section{DISCUSSION}

As a result of the requirements of the milk producers, the emphasis on the health of dairy cows has changed from an individual to a herd level. In this scenario, the recording system and its interpretation by veterinarians have taken a primordial role. The process, which initiated in North America in the 1950s, has extended over a few decades to some Brazilian dairies and has triggered a transformation in the profile of the veterinary services as practiced in the country. Although return on investments is not the sole objective of all dairy health programs, it should be considered the start
Table 4. Causes of 529 cattle losses by slaughter, death, and sanitary culling in a dairy cattle herd from Rio Grande do Sul in the period 2000-2009

\begin{tabular}{|c|c|c|c|}
\hline & Total & $\mathrm{n}(\%)$ & Slaughter reason \\
\hline \multirow[t]{2}{*}{ Slaughter† } & 256 & $\begin{array}{c}144(56.3) \\
86(33.6) \\
26(10.1)\end{array}$ & $\begin{array}{c}\text { Low reproductive performance } \\
\text { Udder / mastitis problems } \\
\text { Others }\end{array}$ \\
\hline & & & Cause of death \\
\hline \multirow[t]{24}{*}{ Death $\ddagger$} & 220 & $36(16.4)$ & Anaplasmosis \\
\hline & & $25(11.4)$ & Leukosis \\
\hline & & $17(7.7)$ & Calf diarrhea \\
\hline & & $13(5.9)$ & $\begin{array}{l}\text { Traumatism due to slippery floor } \\
\text { on the stanchions barn }\end{array}$ \\
\hline & & $13(5.9)$ & Calf pneumonia \\
\hline & & $12(5.5)$ & $\begin{array}{l}\text { Not necropsied or without } \\
\text { a definitive diagnosis }\end{array}$ \\
\hline & & $12(5.5)$ & $\begin{array}{l}\text { Viral interstitial pneumonia } \\
\text { (BRSV and PI-3) }\end{array}$ \\
\hline & & $10(4.5)$ & Metabolic diseases \\
\hline & & $8(3.6)$ & Traumatic reticuloperitonitis \\
\hline & & $8(3.6)$ & Coliform mastitis toxemia \\
\hline & & $7(3.2)$ & $\begin{array}{c}\text { Senecio madagascariensis } \\
\text { poisoning }\end{array}$ \\
\hline & & $6(2.7)$ & Cachexy \\
\hline & & $6(2.7)$ & Stolen-slaughtered cattle \\
\hline & & $6(2.7)$ & Dystocia \\
\hline & & $5(2.3)$ & Babesiosis \\
\hline & & $5(2.3)$ & Black leg \\
\hline & & $4(1.8)$ & $\begin{array}{c}\text { Aspiration pneumonia secondary } \\
\text { to hypocalcemia }\end{array}$ \\
\hline & & $4(1.8)$ & Hemorrhagic enteritis, enterotoxemia \\
\hline & & $3(1.4)$ & Baccharis megapotamica poisoning \\
\hline & & $3(1.4)$ & Grain overload \\
\hline & & $3(1.4)$ & Foamy tympanism (white clover) \\
\hline & & $2(0.8)$ & Anthrax \\
\hline & & $12(5.5)$ & Others \\
\hline & & & Culling reason \\
\hline \multirow{9}{*}{$\begin{array}{l}\text { Sanitary } \\
\text { culling } \neq\end{array}$} & 53 & $25(47.2)$ & TBC reagent with no lesion detected \\
\hline & & $5(9.4)$ & Winter dysentery \\
\hline & & $4(7.5)$ & Uterine rupture \\
\hline & & $4(7.5)$ & Femoral fracture \\
\hline & & $4(7.5)$ & Pi BVDV \\
\hline & & $2(3.8)$ & Metacarpal fracture \\
\hline & & $2(3.8) \mathrm{T}$ & TBC reagent with lesion in 1 lymph node \\
\hline & & $2(3.8)$ & Cachexy \\
\hline & & $5(9.5)$ & Others \\
\hline
\end{tabular}

Bovine respiratory syncytial virus (BRSV); tuberculosis (TBC); persistently infected $(\mathrm{PI})$; bovine viral diarrhea virus (BVDV). † Animals sent to slaughterhouse. $¥$ Animals euthanized (when appropriate), necropsied, and buried in the farm.

point in the establishment of such initiatives. In the United States and Canada, the official recording systems are major factors associated with the increase in milk production levels in the dairy industry (Radostits et al. 1994c). To date, there is no similar system in Brazil; therefore, the maintenance and analysis of records have been carried out based on farm-level record-keeping. In this context, the comparisons between records from similar (management, health, and genetics) herds may become useful tools to the dairy managers, and should be conducted to prevent problems from progressing to more severe issues. However, it should be remembered that procedural differences between studies may make comparisons among these records more difficult. 
Compared to other studies (Durães et al. 2001, Guimarães et al. 2002, Grossi \& Freitas 2002), but in accordance with Val et al. (2004), high levels of milk production were recorded here. Proper nutrition, technological level of management specialization, level of herd health, and genetics are major determinants of variability of productive and reproductive efficiency. Details on nutritional management are beyond of the aim of this report. However, the highest milk productions in this herd were systematically recorded from June to mid December, when the mixed oat/ rye grass/white clover pastures were at their most plentiful and best able to supply the lactation and pregnancy demands of the herd. Most indexes of reproductive performance recorded here indicated comparable efficiency with previous Brazilian (Durães et al. 2001, Leite et al. 2001, Guimarães et al. 2002, Grossi \& Freitas 2002) and other pasture based dairy systems (Grosshans et al. 1997, Garcia \& Holmes 1999, Buckley et al. 2000), but they were moderately (Weaver 1986, Radostits et al. 1994b) or severely inferior (Varner et al. 2010) than those reported for dairy herds in North America, where dairying has long been a high specialized and profitable business mainly associated with housed intensive dairy systems. Reproductive efficiency is ultimately determined by deciding on the postpartum waiting period, heat detection efficiency, and conception rate (Weaver 1986), with the first two factors depending strictly on management decisions. The most striking example of a performance index affected by a management decision was the prolonged (94 days) voluntary postpartum waiting period (VPWP) recorded here. VPWP represents the period after which the reproduction of fresh cows must be restarted. An appropriate VPWP has been reported to be 45-60 days in North American herds (Radostits et al. 1994b), some of which in fact may have up to $80 \%$ of their cows bred by the initial 90 postpartum days (Weaver 1986). However, there has been some controversial evidence regarding optimum calving-toconception (CCI) length (Marsh et al. 1987, Gröhn \& RajalaSchultz 2000). When the mean VPWP value is subtracted from that of $\mathrm{CCl}$, a mean interval of 52 days is obtained. This period includes 2.5 estral cycles and may be associated with either 2.1 services per conception (SPC) or $50 \%$ rate of heat detection, which is much lower than that considered acceptable in USA dairies, for which, however, a 2.1 SPC is shown to be acceptable.

Reproduction efficiency of the lactating cows in this herd was consistently at its lowest in summer months, when it was associated with low rates of heat detection and conception contrasting with high rates of fetal losses (data not shown), but such evidence has long been recognized (Thatcher \& Collier 1986). Cows returning to heat after being diagnosed as pregnant (RHAP) may be considered a measurement of the rate of embryonic and early fetal losses, since first pregnancy diagnosis by rectal palpation was routinely performed in the 30-35 days of the gestational stage. RHAP and abortion rates together represented a total rate of pregnancy losses of 9.8-19.0 and therefore comparable to those recorded in North American (Vasconcelos et al. 1997, Radostits et al. 1994b) and Brazilian dairy herds (Demetrio et al. 2007, Pegorer et al. 2007). Fetal loss rates may be reduced, but will probably never be eliminated. The hypothesis that specific diseases may be responsible for that requires proving and has to be appropriately managed. The herd was fully tested by antiBVDV immunohistochemistry (in ear notch samples) from 2003 to 2006, when 4 animals were identified as persistently infected with BVDV and culled. Also, vaccination programs have systematically been carried out in the herd against brucellosis and leptospirosis, but lately no vaccination against viral diseases with impact on reproduction was performed, since the regular vaccination with a BVDV-IBRBRSV-PI-3 vaccine of the breeding animals from 2000 to 2004 produced no indubitable change in reproductive performance. Moreover, the efficiency of the commercial vaccines available in Brazil against BVDV is controversial (Vogel et al. 2002). However, it has to be kept in mind that no adequate disease control program can depend exclusively on the vaccination, and additional measures of biosafety were usually neglected at this farm, especially with respect to multiple annual entries of cattle without quarantine measures. While quarantine may have no effect on preventing certain chronic diseases, such failures indicate that administrative decisions and sanitary management did not always agree with each other. In addition, non-infectious causes of embryonic and early fetal losses could also be involved (Demetrio et al. 2007, Pegorer et al. 2007, Riet-Correa \& Mendéz 2007, Beltran \& Vasconcelos 2008). Neosporosis was a consistent cause of fetal loss in the herd and contrary to what was observed by Romero et al. (2005), the reproductive performance of NCseropositive cows was lower (Corbellini et al. 2006) than that of the NC-seronegative cows, or even to the herd averages. However, the role of co-infections by additional abortifacient agents in these NC-seropositive cows can not be excluded (Mineo et al. 2006). The reduction in milk production of NC-infected cows (Romero et al. 2005, Radostits et al. 2007a) may be secondary to decreased reproductive performance. Although there were dogs at the farm during all the period studied, the congenital route of infection has been highlighted. Finally, but certainly with no less importance, at least part of the abortion and RHAP problems were secondary to Anaplasma sp. infection (Correa et al. 1978, Radostits et al. 2007b, Kocan et al. 2010).

Together with nutrition and genetics, health completes the fundamental triad of herd management. Therefore, it is important to establish the prevalence of the common diseases affecting the dairy herd for recognizing especial risk situations to be appropriately managed. Anaplasmosis, which has been one of the most important causes of dairy cattle death in the SPV-UFRGS routine (D. Driemeier, data not published), was the most prevalent cause of disease in the herd, but especially in years when tick control was based on insecticide application by manual equipments (knapsack sprayer). After introducing an immersion bath to the 
strategies of control, the prevalence of anaplasmosis declined. Lately (2009-2010), outbreaks of anaplasmosis in the herd have been attributed to hematophagous fly infestation and/or decreased immunity linked to long periods without tick infestation associated with climatic and management conditions (Almeida et al. 2006, Farias 2007, Radostits et al. 2007b). The aforementioned discussion indicates the need of keeping equilibrium between tick infestation and control. Anaplasmosis was routinely treated with oxytetracycline for 3 days. Clinical mastitis was the second most prevalent health disorder in the herd, and occurred at a $27.8 \%$ total mean rate, especially determined by coagulase-negative staphylococci (CNS) and Staphylococcus aureus mammary infections. The CNS are opportunistic and minor causal agents, though they are common pathogens of bovine mastitis in well-managed herds and most are part of the normal teat skin flora. New mammary infections are common, but only clinical cases have been treated and cured easily with intramammary antibiotic / anti-inflammatory therapy for 3-4 days (Philpot \& Nickerson 1991, Radostits et al. 2007c). As expected, Staphylococcus aureus was the major cause of contagious mastitis. During lactation, only clinical $S$. aureus mastitis were treated; otherwise, most infections (58\%) were cured during the dry period, by means of 2-4 mammary infusions of long-acting antibiotics at 20-day intervals. Numbers of mastitis prevalence and CCS were consistent with those recorded in North American (Philpot \& Nickerson 1991, Radostits et al. 1994d) and Brazilian dairy herds (Costa et al. 1995, Cunha et al. 2008).

Ovarian cysts $(O C)$ were also highly frequent dysfunctions, most often observed during summer months (data not shown), when high quality green forage was not consistently available and heat stress was high (LópezGatius et al. 2002). The condition has been reported to affect even more than $20 \%$ of lactating dairy cows (Eyestone \& Ax 1984, Youngquist 1986, Garverick 1997) and have been associated with altered function of the hypothalamichypophysial-ovarian axis (Youngquist 1986, Garverick 1997) possibly influenced by factors such as heredity, milk production and seasonality, among others (Garverick 1997, Lucy 2001). Treatment methods for OC are essential to improve reproductive performance (Garverick 1997) and included synthetic gonadotrophin-releasing hormone $(\mathrm{GnRH})$ singly or in combination with prostaglandin F2á ( PGF $_{2}$ á) eight days apart, progesterone-releasing intravaginal devices associated with GnRH on the same day and $\mathrm{PGF}_{2}$ á nine days later (Youngquist 1986, Garverick 1997), and a simplified puncture and aspiration technique (Cruz et al. 2004) also associated with $\mathrm{GnRH}$ and $\mathrm{PGF}_{2}$ á. Placental retention and postpartum uterine infection exceeded the rates indicated as acceptable $(<20 \%)$ for North American herds (Radostits et al. 1994b). Such high type Holstein herd may be associated with increased proportion of both calving difficulty due to large sized calves and puerperal uterine disorders. Although only a few cows were lost or culled due to complications secondary to dystocia in the period, the level of which was not recorded here, countless large calves were pulled off at birth. A calf mortality rate of $2.2 \%$ mainly associated with diarrhea and pneumonia as major causes is consistent with the percentages reported in North American herds (Radostits et al. 1994e). It is possible and even probable that some of these losses were consequences of failures in the colostrum management, which is the main topic in dairy calf health programs. Digital diseases have been recognized as a major problem of dairy cows also in Brazil (Molina et al. 1999, Cruz et al. 2001, Silveira et al. 2009). Among the digital disorders, digital dermatitis was the most prevalent and has been especially associated with muddy underfoot conditions determined by rainy weather and overcrowding. Claw disorders were sporadic and associated with low availability of high quality fiber (Greenough \& Vermunt 1991, Nocek 1997), especially in the transition periods (winter-spring to summer months and contrariwise). Babesiosis, traumatic reticulitis, and abomasal displacement were sporadic conditions mostly associated with particular management situations such as importation of heifers from tick-free areas, periods of facilities (fences, barns) constructions, and periods of high quality fiber scarcity or nutritional transition (low fiber intake), respectively. Adult pneumonia was sporadic, but apparently linked to extreme temperatures, humid whether and viral interstitial pneumonia by BRSV and $\mathrm{PI}-3$ virus infections. Metabolic diseases were important in high producing cows, which failed consecutively to conceive, became high scored, and experienced prolonged dry periods. Locomotion deficiency secondary to necrosis of the rear leg muscles is severe and limiting sequelae of delayed therapy in these cases. Once again the importance of nocturne parturition care must be emphasized since this is the most important stage to keep a close observation on the cows.

Low reproductive performance was the most common among all culling reasons and was associated with problems such as exceeded services per conception in consecutive years, consecutive conception failure, highly extended postpartum anestrus, and repetitive fetal losses. Neosporosis, inadequate management (nutritional deficiencies and improper management decisions), genetics (heredity in families of cows with low reproductive performance), and advanced age (cows older than 8 years of age) were some of the causes associated with this scenario. Similar numbers (since $56.3 \%$ was the total rate in the 10-year period) have been recorded as acceptable in North American (5-8\% annually) herds (Weaver 1986, Radostits et al. 1994b). While considerable part of this problem may have originated from improper management, a clear antagonistic relationship has been recognized between milk production and reproduction in dairy cattle in North America (Lucy 2001, Lucy 2007), from where most genetics has been introduced in this herd. Main causal reasons for culling by udder problems included loose central mammary cleft, wide front teat placement, loss of teats and quarters by mastitis, and chronic or relapsing mammary infection. Bovine leukosis 
was the most common cause of death in the beginning of period studied (data not shown), when culling rates were at their lowest, since there was the need to increase the herd size and cows grew older in the farm, providing an increased risk of clinical bovine lymphoma (Radostits et al. 2007d). Measures applied as attempts to minimize the disease dissemination included the use of dischargeable needs and gloves, apart from a free-leukosis colostrum bank. However, unfortunately the results of such measures have not been evaluated to date. When the total period is considered, anaplasmosis was the main cause of cattle death in the herd.

Brucellosis has been an absent disease in this herd for over twenty years (there were six positive reactors only at the first herd testing in 1988; thereafter it is suggested that $B$. abortus strain 19 vaccine has been a highly effective control measure). On the other hand, reaction in tuberculin tests has been the main reason for sanitary culling. Owners have accepted the losses attributed to the euthanasia, necropsy and burial of animals at the farm with a view to increasing the chances to detect discrete lesions and as an attempt to identify the real picture of the disease in the herd. From 2000 to 2002, 8 reactors did not show lesions at necropsy. From 2002 to 2006 , no reactors at all were observed; however, from 2007 to 2009 , a total of 19 reactors were detected, two of which presenting lymph nodal lesions characteristic of tuberculosis. Though some of these reactors could have been false positive, the risk of maintaining infected animals disseminating the disease in such valuable herd justified the culling. Most (22) of these 27 reactors were animals that had been introduced (2006) in the herd, which emphasizes the severe risk that introducing cattle may represent to the herd biosafety. All these animals were anergic at the first test, and were detected in subsequent tests. Reasons why animals delayed to react may include the inherent chronicity of the disease, or an initial desensitization. While the exact numbers of the prevalence of the disease in Brazil remain unknown (Riet-Correa \& Garcia 2007), an apparent mean prevalence of $1-2 \%$ has been indicated in reports of limited herd testing (Poletto et al. 2004, Oliveira et al. 2007, Associação Brasileira de Buiatria 2010) and slaughtering (Andrade et al. 1991, Fernandes et al. 2003, Ribeiro et al. 2003, Baptista et al. 2004). In addition, surveys at abattoirs may invariably underestimate tuberculosis prevalence, since the usual line of slaughter is too fast and may not spare the time required to search for lesions, and thus only the most evident lesions are likely to be observed in such way. The Programa Nacional de Controle e Erradicação de Tuberculose e Brucelose (PNCEBT), currently existing in Brazil certificate voluntary herds as tuberculosis-free after three consecutive herd tests with negative results. On the other hand, the compulsory testing and slaughter of reactors has been the only satisfactory method by which effective eradication of tuberculosis has been achieved in many countries (Radostits et al. 2007e). Compensation for full cooperation and adequate training of official veterinary supervisors are additional critical points on PNCEBT. Payment for animals destroyed probably increases the likelihood that herdsmen have additional reasons for identifying, reporting, and slaughtering positive reactors. Veterinarians involved in tuberculosis control should keep in mind that culling and adequate disposing of positive reactors is the primordial objective of a tuberculin herd testing protocol. If there is no intention of disposing of reactors, there is no reason for testing herds. Other causes of sanitary culling included just sporadic events.

While most indexes of reproductive performance presented here were comparable with those of previous Brazilian reports, part of the data presented here has not been divulged, though it may be present at farm-level. Besides, the indexes were worse than those recorded under intensive farming in highly specialized North American dairies (Weaver 1986, Radostits et al. 1994b, Varner et al. 2010). It is suggested that the main reason for this condition in most Brazilian dairy herds may be associated with some degree of deficient nutrition rather than with health and genetics restrictions. However, the role of genetics in the scenario presented here can not be underestimated (Lucy 2007). On the other hand, it may be said that the targets of performance for North American dairy cattle may not be applicable for most of the Brazilian dairies, since there are considerable differences among numerous aspects linked to dairying in North and South Americas, which is an additional justification for this report. Moreover, even in North American dairies, evidence has shown that targets of reproductive efficiency may be variable (Marsh et al. 1987, Gröhn \& Rajala-Schultz 2000). In this context, the performance recorded in foreign pasture based dairy systems may serve as patterns of comparisons with those reported here. The information included here contributes to the determination of the ranges of the targets of performance of Brazilian dairy cattle and provides useful tools for managers and veterinarians involved in dairy cattle herd health, management and production.

Aknowledgements.- To Granja e Cabanha VB for cooperating with this study. This study was funded by The Conselho Nacional de Desenvolvimento Científico e Tecnológico (CNPq), Brazil.

\section{REFERENCES}

Almeida M.B., Tortelli F.P., Riet-Correa B., Ferreira J.L.M., Soares M.P., Farias N.A.R., Riet-Correa F. \& Schild A.L. 2006. Tristeza parasitária bovina na região sul do Rio Grande do Sul: estudo retrospectivo de 1978-2005. Pesq. Vet. Bras. 26(4):237-242.

Andrade G.B., Riet-Correa F., Mielke P.V., Mendes M.C. \& Schild A.L. 1991. Estudo histológico e isolamento de micobactérias de lesões similares a tuberculose em bovinos no Rio Grande do Sul. Pesq. Vet. Bras. 11:81-86.

Associação Brasileira de Buiatria - TbBovNet. Available at <http:// www.mgar.vet.br/buiatria/tbbovnet> Accessed on June 23, 2010.

Baptista F., Moreira E.C., Santos W.L.M. \& Naveda L.A.B. 2004. Prevalência da tuberculose em bovinos abatidos em Minas Gerais. Arq. Bras. Med. Vet. Zootec. 56(5):577-580.

Beltran M.P. \& Vasconcelos J.L.M. 2008. Conception rate in Holstein cows treated with $\mathrm{GnRH}$ or hCG on the fifth day post artificial 
insemination during summer. Arq. Bras. Med. Vet. Zootec. 60(3):580586.

Buckley F., Dillon P., Rath M. \& Veerkamp R.F. 2000. The relationship between genetic merit for yield and live weight, condition score, and energy balance of spring calving Holstein Friesian dairy cows on grass based systems of milk production. J. Dairy Sci. 83:18781886.

Costa E.O., Melville P.A., Ribeiro A.R., Watanabe E.T., White C.R. \& Pardo R.B. 1995. Índices de mastite bovina clínica e subclínica nos Estados de São Paulo e Minas Gerais. Rev. Bras. Med. Vet. 17:215217.

Corbellini L.G., Pescador C.A., Frantz F., Wunder E., Stefen D., Smith D. \& Driemeier D. 2006. Diagnostic survey of bovine abortion with special reference to Neospora caninum infection: Importance, repeated abortion and concurrent infection in aborted fetuses in Southern Brazil. Vet. Journal 172(1):114-120.

Correa W.M., Correa C.N.M. \& Gottschalk A.F. 1978. Bovine abortion associated with Anaplasma marginale. Can. J. Comp. Med. 42:227228.

Cruz C.E.F., Driemeier D., Cerva C. \& Corbellini L.G. 2001. Clinical and epidemiological aspects of bovine digital lesions in southern Brazil. Arq. Bras. Med. Vet. Zootec. 53(6):654-657.

Cruz C.E.F., Corbellini L.G. \& Driemeier D. 2004. A simple procedure for emptying long-term ovarian cysts in cattle. Vet. Rec. 155(19):599601.

Cunha R.P.L., Molina L.R., Carvalho A.U., Facury Filho E.J., Ferreira P.M. \& Gentilini M.B. 2008. Mastite subclínica e relação da contagem de células somáticas com número de lactações, produção e composição química do leite em vacas da raça Holandesa. Arq. Bras. Med. Vet. Zootec. 60(1):19-24.

Demetrio D.G.B., Santos R.M., Demetrio C.G.B. \& Vasconcelos J.L.M. 2007. Factors affecting conception rates following artificial insemination or embryo transfer in lactating Holstein cows. J. Dairy Sci. 90:5073-5082.

Durães M.C., Freitas A.F., Valente J., Teixeira N.M. \& Barra R.B. 2001 Tendência genética para a produção de leite e de gordura em rebanhos da raça holandesa no estado de Minas Gerais. Revia Bras. Zootec. 30(1):66-70.

Eyestone W.H. \& Ax R.L. 1984. A review of ovarian follicular cysts in cows, with comparisons to the condition in women, rats and rabbits. Theriogenology 22:109-125.

Farias N.A. 2007. Tristeza parasitária bovina, p.524-532. In: Riet-Correa F., Schild A.L., Lemos R.A.A. \& Borges J.R.J. (Eds), Doenças de Ruminantes e Equídeos. Vol.1. $3^{\mathrm{a}}$ ed. Pallotti, Santa Maria. 722p.

Fernandes J.O.M., Neto R.S., Silva H.L., Soares C., Silva P., Soutello R.V.G., Borges J.H.R., Faria R.F., Coelho R.V., Tanaka D., Fialho Sousa C.H. \& Dias A.E. 2003. Prevalência da tuberculose bovina determinada através de exames realizados em carcaças de bovinos abatidos no município de Andradina-SP. Ciência Agrícola da Saúde FEA 3(2):7-12.

Garcia S.C. \& Holmes C.W. 1999. Effects of time of calving on the productivity of pastured-based dairy systems. N. Z. J. Agr. Res. 42:347-362.

Garverich H.A. 1997. Ovarian follicular cysts in dairy cows. J. Dairy Sci. 80:995-1004.

Greenough P.R. \& Vermunt J.J. 1991. Evaluation of subclinical laminitis in a dairy herd and observations on associated nutritional and management factors. Vet. Rec. 128:11-17.

Gröhn Y.T. \& Rajala-Schultz P.J. 2000. Epidemiology of reproductive performance in dairy cows. Anim. Reprod. Sci. 60-61:605-614.

Grosshans T., Xu Z.Z., Burton L.J., Johnson D.L. \& Macmillan K.L. 1997. Performance and genetic parameters for fertility of seasonal dairy cows in New Zealand. Livest. Prod. Sci. 51:41-51.
Grossi S.F. \& Freitas M.A.R. 2002. Eficiência reprodutiva e produtiva em rebanhos leiteiros comerciais monitorados por sistema informatizado. Revta Bras. Zootec. 31(3):1362-1366.

Guimarães J.D., Alves N.G., Costa E.P., Silva M.R., Costa F.M.J. \& Zamperlini B. 2002. Eficiências reprodutiva e produtiva em vacas das raças Gir, Holandês e Cruzadas Holandês x Zebu. Revta Bras. Zootec. 31(2):641-647.

Kocan K.M., De La Fuente J., Blouin E.F., Coetzee J.F. \& Swing S.A. 2010. The natural history of Anaplasma marginale. J. Vet. Parasitol. 167: 95-107.

Leite T.E., Moraes J.C.F. \& Pimentel C.A. 2001. Eficiência produtiva e reprodutiva em vacas leiteiras. Ciência Rural 31(3):467-472.

López-Gatius F., Santolaria P., Yánez J., Fenech M. \& López-Béjar M. 2002. Risk factors for postpartum ovarian cysts and their spontaneous recovery or persistence in lactating dairy cows. Theriogenology 58(8):1623-1632.

Lucy M.C. 2001. Reproductive loss in high-producing dairy cattle: Where it will end? J. Dairy Sci. 84:1277-1293.

Lucy M.C. 2007. Fertility in high-producing dairy cows: reasons for decline and corrective strategies for sustainable improvement. Soc. Reprod. Fertil. 64(Suppl.):237-354.

Marsh W.E., Dijkhuizen A.A. \& Morris R.S. 1987. An economic comparison of four culling decision rules for reproductive failure in United States dairy herds using DairyOracle. J. Dairy Sci. 70:12741280.

Mineo T.W., Alenius S., Näslund K., Montassier H.J. \& Björkman C. 2006. Distribution of antibodies against Neospora caninum, BVDV and BHV-1 among cows in brasilian dairy herds with reproductive disorders. Revta Bras. Parasitol. Vet. 15(4):188-192.

Molina L.R., Carvalho A.U., Facury Filho E.J., Ferreira P.M. \& Ferreira V.C.P. 1999. Prevalência e classificação das afecções podais em vacas lactantes na bacia leiteira de Belo Horizonte. Arq. Bras. Med. Vet. Zootec. 51(2):149-152.

Morrow D.A. 1986. Current Therapy in Theriogenology. 2. Diagnosis, treatment and prevention of reproductive diseases in small and large animals. 2nd ed. W.B. Saunders, Philadelphia, p.1083-1104.

Nocek J.E. 1997. Bovine acidosis: Implications on laminitis. J. Dairy Sci. 80(5):1005-1028.

Oliveira I.A.S., Mello H.P.C., Câmara A., Cunha Dias R.V. \& SotoBlanco B. 2007. Prevalência de tuberculose no rebanho bovino de Mossoró, Rio Grande do Norte. Braz. J. Vet. Res. Anim. Sci. 44(6): 395-400.

Pegorer M.F., Vasconcelos J.L.M., Trinca L.A., Hansen P.J. \& Barros C.M. 2007. Influence of sire and sire breed (Gyr versus Holstein) on establishment of pregnancy and embryonic loss in lactating Holstein cows during summer heat stress. Theriogenology 67(4):692-697.

Philpot W.N. \& Nickerson S.C. 1991. Mastitis: Counter attack. Babson Bros, Illinois. 150p.

Poletto R., Kreutz L.C., Gonzales J.C. \& Barcellos L.J.G. 2004. Prevalência de tuberculose, brucelose e infecções víricas em bovinos leiteiros do município de Passo Fundo, RS. Ciência Rural 34(2):595598.

Portela J.N., Viegas J., Neumann P.S., Luarentino L.D. \& Castagnino G. 2002. Indicadores de desempenho zootécnico observados nas unidades de produção familiar associadas à cooperativa dos produtores de leite de Santa Maria (COOPROL), RS. Ciência Rural 32(3): 855-861.

Radostits O.M., Leslie K.E. \& Fetrow J. 1994a. Dairy Health and Production Management Program, p.97-140. In: Ibid. (Eds) Herd Health. $2^{\text {nd }}$ ed. W.B. Saunders, Philadelphia.

Radostits O.M., Leslie K.E. \& Fetrow J. 1994b. Maintaining Reproductive Efficiency in Dairy Cattle, p.141-158. In: Ibid. (Eds) Herd Health. $2^{\text {nd }}$ ed. W.B. Saunders, Philadelphia. 
Radostits O.M., Leslie K.E. \& Fetrow J. 1994c. Record Systems and Herd Health, p.49-71. In: Ibid. (Eds) Herd Health. $2^{\text {nd }}$ ed. W.B. Saunders, Philadelphia.

Radostits O.M., Leslie K.E. \& Fetrow J. 1994d. Mastitis Control in Dairy Herds, p.229-276. In: Ibid. (Eds) Herd Health. $2^{\text {nd }}$ ed. W.B. Saunders, Philadelphia.

Radostits O.M., Leslie K.E. \& Fetrow J. 1994e. Health Management of Dairy Calves and Replacement Heifers, p.183-228. In: Ibid. (Eds) Herd Health. $2^{\text {nd }}$ ed. W.B. Saunders, Philadelphia.

Radostits O.M., Gay C.C., Hinchcliff K.W. \& Constable, P.D. 2007a. Neosporosis, p.1509-1512. In: Ibid. (Eds) Veterinary Medicine. $10^{\text {th }}$ ed. Saunders Elsevier, Oxford.

Radostits O.M., Gay C.C., Hinchcliff K.W. \& Constable, P.D. 2007b. Anaplasmosis, p.1455-1459. In: Ibid. (Eds) Veterinary Medicine. $10^{\text {th }}$ ed. Saunders Elsevier, Oxford.

Radostits O.M., Gay C.C., Hinchcliff K.W. \& Constable, P.D. 2007c. Bovine mastitis, p.673-697. In: Ibid. (Eds) Veterinary Medicine. 10 ${ }^{\text {th }}$ ed. Saunders Elsevier, Oxford.

Radostits O.M., Gay C.C., Hinchcliff K.W. \& Constable, P.D. 2007d. Enzootic bovine leukosis (bovine lymphosarcoma), p.1209-1221. In: Ibid. (Eds) Veterinary Medicine. $10^{\text {th }}$ ed. Saunders Elsevier, Oxford.

Radostits O.M., Gay C.C., Hinchcliff K.W. \& Constable, P.D. 2007e. Diseases associated with Mycobacterium sp., p.1007-1044. In: Ibid. (Eds) Veterinary Medicine. $10^{\text {th }}$ ed. Saunders Elsevier, Oxford.

Ribeiro A.R.P., Lobato F.C.F., Abreu V.L.V., Faria E.S. \& Silva J.A. 2003. Prevalência de tuberculose e brucelose bovina no município de Ilhéus. Arq. Bras. Med. Vet. Zootec. 55(1):120-122.

Riet-Correa F. \& Garcia M. 2007. Tuberculose, p.432-442. In: RietCorrea F., Schild A.L., Lemos R.A.A. \& Borges J.R.J. (Eds), Doenças de Ruminantes e Equídeos. Vol.1. $3^{\underline{a}}$ ed. Pallotti, Santa Maria.

Riet-Correa F. \& Méndez M.C. 2007. Intoxicações por Plantas e Micotoxinas, p.99-221. In: Riet-Correa F., Schild A.L., Lemos R.A.A. \& Borges J.R.J. (Eds), Doenças de Ruminantes e Equídeos. Vol.1. 3a ed. Pallotti, Santa Maria.

Romero J.J., Breda S.V., Vargas B., Dolz G. \& Frankena K. 2005.
Effect of neosporosis on productive and reproductive performance of dairy cattle in Costa Rica. Theriogenology 64(9):1928-1939.

Silveira J.A.S., Albernaz T.T., Oliveira C.M.C., Duarte M.D. \& Barbosa J.D. 2009. Afecções podais em vacas da bacia leiteira de Rondon do Pará. Pesq. Vet. Bras. 29(11):905-909.

Schwabe C. 1982. The current epidemiological revolution in veterinary medicine. Part 1. Prev. Vet. Med. 1:5-15.

Thatcher W.W. \& Collier R.J. 1986. Effects of climate on reproduction in dairy cattle, p.383-389. In: Morrow D.A. (Ed.), Current Therapy in Theriogenology. 2. Diagnosis, Treatment and Prevention of Reproductive Diseases in Small and Large Animals. $2^{\text {nd }}$ ed. W.B. Saunders, Philadelphia.

Varner M.A., Majeskie J.L. \& Garlichs S.C. 2010. Interpreting reproductive efficiency indexes. Available at <http://www.wvu.edu/ agexten/ forglvst/Dairy/dirm5.pdf> Accessed on May 14, 2010.

Vasconcelos J.L.M., Silcox R.W., Lacerda J.A., Pursley J.R. \& Wiltbank M.C. 1997. Pregnancy rate, pregnancy loss, and response to heat stress after $\mathrm{Al}$ at 2 different times from ovulation in dairy cows. Biol. Reprod. 56:140. (Abstract)

Val J.E., Freitas M.A.R., Oliveira H.N., Cardoso V.L., Machado P.F. \& Paneto J.C.C. 2004. Indicadores de desempenho em rebanho da raça Holandesa: curvas de crescimento e altura, características reprodutivas, produtivas e parâmetros genéticos. Arq. Bras. Med. Vet. Zootec. 56(1):86-93.

Vogel F.S.F., Flores E.F., Weiblen R., Mayers S.V., Quadros V.L. \& Oldoni I. 2002. Magnitude, duração e especificidade da resposta sorológica em bovinos vacinados contra o vírus da diarréia viral bovina (BVDV). Ciência Rural 32(1):83-89.

Weaver L.D. 1986. Reproductive management programs for large dairies, 383-389. In: Morrow D.A. (Ed.), Current Therapy in Theriogenology. 2. Diagnosis, treatment and prevention of reproductive diseases in small and large animals. $2^{\text {nd }}$ ed. W.B. Saunders, Philadelphia.

Youngquist R.S. 1986. Cystic follicular degeneration in the cow, p.243246. In: Morrow D.A. (Ed.), Current Therapy in Theriogenology. 2. Diagnosis, Treatment and Prevention of Reproductive Diseases in Small and Large Animals. $2^{\text {nd }}$ ed. W.B. Saunders, Philadelphia. 